Pro Musica Sacra 16 (2018), s. 7-8

DOI: http://dx.doi.org/10.15633/pms.2574

\title{
Dziesięć lat Międzyuczelnianego Instytutu Muzyki Kościelnej w Krakowie
}

W tym roku mija właśnie 10 lat od historycznego wydarzenia, kiedy to prof. Stanisław Krawczyński, rektor Akademii Muzycznej w Krakowie, i ks. prof. Jan Maciej Dyduch, rektor Papieskiej Akademii Teologicznej w Krakowie (dzisiaj UPJPII), dokładnie 19 listopada 2008 roku w Domu Arcybiskupów Krakowskich podpisali w obecności Wielkiego Kanclerza UPJPII kard. Stanisława Dziwisza umowę o współpracy obu uczelni w prowadzeniu wspólnie kierunku muzyka kościelna. Stworzyli też wówczas Międzyuczelniany Instytut Muzyki Kościelnej w Krakowie. To pierwszy i jedyny jak dotąd taki instytut naukowo-dydaktyczny w Polsce. Jak więc nie dziękować dzisiaj Bogu i ludziom, którzy uczestniczyli w przygotowaniu tego wydarzenia i tworzeniu fundamentów dla ośrodka, który do dziś dba o muzykę kościelną.

Dwa lata wcześniej (w 2006 roku) rozpoczęły się prace międzyuczelnianej komisji, w skład której weszli ks. prof. Andrzej Zając, prof. Wiesław Delimat, prof. Jan Jazownik, prof. Adam Korzeniowski i piszący te słowa. Zadaniem komisji było przygotowanie wszystkich dokumentów potrzebnych do prowadzenia nowego kierunku. Data 1 lutego 2008 roku zapisze się już na zawsze jako dzień udzielenia pozwolenia - dla obu uczelni - na prowadzenie jedynego wówczas w Polsce kierunku „muzyka kościelna” przez Ministra Nauki i Szkolnictwa Wyższego. Uczelniom otwarło to możliwość prowadzenia działalności w tym zakresie, ale także na przyszłość większej dbałości o jakość muzyki kościelnej. Ważnym wydarzeniem dla Instytutu w tych 10 latach z całą pewnością było pobłogosławienie w dniu 26 października 2011 roku przez kard. Stanisława Dziwisza organów piszczałkowych Międzyuczelnianego Instytutu Muzyki Kościelnej w kościele Świętego Stanisława Biskupa i Męczennika w Krakowie-Dąbiu. Zapisze się na zawsze w historii także fakt nadania w dniu 4 lipca 2015 roku w Castel Gandolfo - z inspiracji naszego Instytutu - doktoratu honoris causa Akademii Muzycznej i Uniwersytetu Papieskiego papieżowi emerytowi Benedyktowi XVI. A ilu wspaniałych pedagogów i studentów oraz pracowników tworzyło to dzieło? Ile dobra dokonało się w nas i w tych, którzy chcieli przyjąć Bożą łaskę? Za to wszystko z radością śpiewamy Te Deum laudamus... oraz dziękujemy wszystkim ludziom, którzy pomogli w stworzeniu owego dzieła. 
Dzisiaj oddajemy także do Państwa rąk kolejny numer naszego czasopisma „Pro Musica Sacra”, które powstało po I Ogólnopolskim Kongresie Muzyki Liturgicznej Musicam Sacram promovere, zorganizowanym we wrześniu 2004 roku w Krakowie. W tym numerze prócz ważnego artykułu o historii naszego Instytutu autorstwa ks. prof. Andrzeja Zająca odnajdziemy artykuły: ks. Vincenzo de Gregorio z Rzymu, ks. Gilberta Sessantiniego z Bergamo, ks. Mariusa Linnerborna z Trier oraz ks. Wojciecha Kałamarza. Są one ważnymi głosami Kościoła w 50-lecie instrukcji watykańskiej z 1967 roku Musicam Sacram. Kolejne teksty są biblijnymi spojrzeniami na muzykę, powiązaniem myśli Josepha Ratzingera i muzyki Henryka Mikołaja Góreckiego, omówieniem problematyki nieszporów jasnogórskich, mszy Rorate, a także kolejnych opracowań z Archiwum Krakowskiej Kapituły Katedralnej na Wawelu. Oczywiście nie brakuje także recenzji, komunikatów i sprawozdań. Niniejszy numer naszego czasopisma dedykujemy wszystkim, którzy tworzyli i tworzą Międzyuczelniany Instytut Muzyki Kościelnej w Krakowie. Życzymy im, aby nieustannie poszukiwali „drogi piękna” i odkrywali ją w codziennym działaniu, a ona z pewnością doprowadzi wszystkich do oglądania Piękna samego Boga.

ks. dr hab. Robert Tyrała, prof. UPJPII redaktor naczelny „Pro Musica Sacra” prorektor UPJPII w Krakowie 